\title{
A.S. BYATT AND THE "PERPETUAL TRAVELLER": A READING PRACTICE FOR NEW BRITISH FICTION
}

\author{
Nicole FLYNN \\ South Dakota State University \\ nicole.flynn@sdstate.edu
}

\begin{abstract}
While most readers enjoyed, or at least admired A.S. Byatt's Booker prize-winning novel Possession, many are puzzled by her work before and since. This essay argues that the problem is not the novels themselves, but rather the way that readers approach them. Conventional reading practices for experimental or postmodern fiction do not enable the reader to understand and enjoy her dense, dizzying work. By examining the intertexts in her novella "Morpho Eugenia," in particular two imaginary texts written by the protagonist William Adamson, this essay demonstrates how the novella generates a different kind of reading practice. Using Byatt's metaphor, the essay recommends that readers become "perpetual travelers," a global model of readership that will enable readers to navigate not only Byatt's oeuvre and the realm of neo-Victorian fiction, but also the field of new British fiction and the crowded media landscape in which it resides.
\end{abstract}

Keywords: Angels and Insects, historical fiction, novel, British literature, hermeneutics, intertextuality. 
NICOLE FLYNN

\title{
A.S. BYATT Y EL "VIAJERO PERPETUO": UNA PRÁCTICA LECTORA DE LA NUEVA FICCIÓN BRITÁNICA
}

\begin{abstract}
RESUMEN. Aunque la mayoría de los lectores disfrutaron o por lo menos admiraron la novela Possession, escrita por A.S. Byatt, y merecedora del premio Booker, muchos se han quedado desconcertados por su obra de antes y después. Este artículo defiende que el problema no reside en las novelas en sí mismas, sino en la manera en que los lectores se acercan a las mismas. La lectura convencional que se suele llevar a cabo de la ficción postmoderna o experimental no le permite al lector entender y disfrutar de la obra densa y mareante de esta escritora. A través del análisis intertextual de su novela corta "Morpho Eugenia", y en particular de dos textos imaginarios escritos por el protagonista, William Adamson, este articulo demuestra la manera en que la novela corta genera un tipo diferente de lectura. Siguiendo la metáfora de Byatt, en este artículo se recomienda que los lectores se conviertan en "viajeros perpetuos", un modelo global de lectura que permitrá navegar no sólo por la obra de Byatt y el terreno de la ficción neo-victoriana, sino también por el campo de la nueva ficción británica y el populoso paisaje mediático en el que reside esta última.
\end{abstract}

Palabras clave: Ángeles e insectos, ficción histórica, novela, literatura británica, intertextualidad.

Received 17 October 2017

Revised version accepted 29 May 2018

The past is a foreign country: they do things differently there. - The Go-Between, L. P. Hartley

And any good reader ought to have a kind of neutral gear... a kind of wandering, scanning reading which is a reenacting reading. - A.S. Byatt

The success of A.S. Byatt's Booker-prize winning Possession: A Romance (1990) secured her position within the literary world and illustrated the ascendancy of the neo-Victorian novel. Her next book, a pair of novellas entitled Angels and Insects (1992), revisited the Victorian era. Despite the genre's growing popularity, Byatt's work continued to puzzle critics, readers, and scholars. John Barrell began his review for the London Review of Books: "I don't quite know what to say about Angels and Insects" (1992: 18). He goes on to assert that he admires what Byatt accomplishes, but he doesn't see the point - he can't figure out "the idea behind these novellas" (1992: 18). For many readers, even savvy, professional readers 
like Barrell, Byatt's novels present an insurmountable obstacle to comprehension, enjoyment, or both. The historical turn within the field of contemporary British fiction met with resistance too. Historical fiction, especially "literary" historical fiction published in the past few decades, has been accused of "random cannibalization of all the styles of the past", "blurring of the distinction between history and literature", and "fancy-dress worldmaking" (Jameson 1991: 18; Holmes 1997: 13; Keen 2006: 176). This essay argues that the problem is not the novels themselves or their genre, but rather the readers' approach to them. Byatt's fiction illustrates the problem and provides a solution. Too often readers burrow through her books in an attempt to unveil the Idea beneath the dense cover of metaphor and allusion that characterizes her fiction. While this may be a tested approach for readers of fiction in the wake of postmodernism, we must search for a different reading practice to understand and enjoy Byatt's "self-conscious realism" (Byatt 1992b: xv). This essay contends that "Morpho Eugenia", the first novella in Angels and Insects, promotes a unique reading practice, a practice that transforms the reader into a "perpetual traveller" (Byatt 1992a: 18). The metaphor "perpetual traveller" is taken from the novella itself - the protagonist William Adamson uses it to describe a colony of ants that he wishes to study. It characterizes a practice that requires the reader to work, yet affords pleasure, that sends the reader on journey without beginning or end, a private practice that potentially shifts the paradigm of reading within public discourse. Using "Morpho Eugenia" as a case study, this essay suggests that readers willing to become perpetual travellers will be better equipped to navigate Byatt's novels, historical fiction, New British Fiction and the crowded and ever-changing media landscape they occupy.

The idea of reader as perpetual traveller may seem counterintuitive when approaching a realist novella set in a Victorian manor home. Unlike Possession, which jumps back and forth between the nineteenth and the twentieth centuries, Byatt sets Angels and Insects entirely in the 1860s. For some, this nestles the text further away from contemporary concerns. Indeed, those who criticize historical fiction often accuse its authors and readers of a problematic nostalgia and insularity, reminiscing about colonial England instead of confronting and depicting issues in today's global society. ${ }^{2}$ This essay will explain how the perpetual-traveller reading practice can combat such concerns about insularity within Byatt's oeuvre and beyond. Contrary to the standard view, Byatt contends that "aggressively 'experimental' fiction", in its attempt to open up a space for reader-participation, actually restricts the reader with "distracting devices" (Byatt 1992b: 157). In her

\footnotetext{
1 Byatt's own term.

2 Perhaps the most strident example being the manifesto by Matt Thorne and Nicolas Blincoe in All Hail the New Puritans in which they vow that "our texts will avoid all improbable or unknowable speculations on the past or the future" (i).
} 
words, such fiction "teases the reader and demands total admiration and assent"; it is "more exclusive of mental activity in the readers" (Byatt 1992b: xvi). The type of novel she writes, "leaves space for [...] dissent and qualification", for "independent thought" in the reader (Byatt 1992b: xv, xvi). She critiques John Fowles, author of The French Lieutenant's Woman (1969), a novel most critics consider a forerunner to her historical fiction, for restricting the reader in this way. Although Fowles claims that he wrote multiple possible endings to his novel so as to avoid "control[ing] his characters", Byatt counters: "his projected endings do not suggest a plurality of possible stories [...] these alternative endings are neither future nor conditional, but fixed, Victorian, narrative past" (Byatt 1992b: 155). Alternatively, if endings stay in the realm of the possible, as she believes hers do, "they intensify the reality of the future world" for the reader (Byatt 1992b: 155). In other words, by borrowing from the historical realist tradition, Byatt's neo-Victorian fiction actually enables a more active, participatory reading experience in the present and a more credible vision of the future.

Rather than beginning with externally generated terminology, the metaphor "perpetual traveler" helps us to approach the text on its own terms. Furthermore, using a metaphor acknowledges the central role that this type of figurative language plays in Byatt's work. Susan Poznar uses a similar tactic in her analysis of "Conjugial Angel". She compares the novella to "the shining cocoon that the medium Sophy Sheeky perceives spinning itself around the aged Alfred Tennyson" and describes it as "haunted, not only by spirit voices but also by the voices of contemporary literary debate" (Poznar 2004: 174, 175). Julian Gitzen asserts that, "For Byatt the most powerful feature of language remains metaphor, that imaginative vehicle of implied or explicit comparisons" (1995: 88). By choosing a metaphor from the novella to depict the reading practice that the novella recommends, we harness a powerful vehicle for understanding a complex relationship between text and reader.

However, the metaphors in "Morpho Eugenia" often seem too excessive to offer the reader any explicit comparisons. Set in a newly Darwinian world, the novella depicts the heady excitement surrounding the possibility that a single theory could explain everything. Likewise, it depicts the crisis of faith that such a theory could produce. According to Sally Shuttleworth, "Morpho Eugenia" takes place at a moment when "the study of the order of nature transmuted into a lament for its disorder" (2001: 151). Byatt highlights this conflict in the character of Sir Harald Alabaster, an Anglican minister grappling with the coincidence of his belief in science and in God, debating the matter with William and with himself in his tautological treatise on natural theology. In terms of reading practice, the problem is not Darwin's theory itself but rather the use of his theory as an interpretive 
model. Many readers are understandably drawn to this trope in the novella; the attempt to exert order, to find a system that would contain the chaos of encroaching modernity seems a fitting parallel to reading Byatt's fiction. Michael Levenson articulates both the Victorian and the contemporary academic's desire for such a universalizing theory: "There remained the hope, continually enacted in Angels and Insects, that the new unsettling facts could be accommodated though nimble argument. In this sense, our own literary theory is a late, parodic form of a once momentous conflict" (Levenson 2001: 162). Although William relies on metaphor to articulate his world view ("he was hard put to it not to see his own life in terms of a diminishing analogy with the tiny creatures"), Levenson points out that even William resists this pull (Byatt 1992a: 116). Levenson posits, "William Adamson is as inveterate a user of analogy as all those defensive theorists who seek to disarm the world's contingency. Yet, the difference, which is all the difference, is that his analogical imagination makes no attempt to stabilize the world" (2001: 170). By setting the novel in this transitional moment in history, in which the characters are unsure which direction to move or how to reconcile oppositional systems of organization and belief, Byatt frees readers from the necessity of choosing sides.

Byatt is not the only neo-Victorian author at the end of the twentieth century to feature this transitional moment in her fiction. ${ }^{3}$ As Shuttleworth argues, this moment attracts many contemporary novelists because the "realm of extra human order", on which both natural theology and Darwinism depends, "has a tendency to unravel and implode. Neither term in the equation remains stable" (2001: 151). Heidi Hansson notes a parallel tendency in Byatt's style. Since her readers continually move back and forth from the literal to the figurative, meaning is always somewhat in flux. Hansson dubs Angels and Insects a "postmodern allegory" because both the literal and figurative meanings are unstable or variable (1999: 455). This tendency towards instability, unraveling, and implosion likewise highlights the potential pitfalls of using Byatt's metaphors as a hermeneutic model. Their attractiveness is undeniable - Hansson discusses the reader's compulsion to sort through the "too much message, or too many messages" of Byatt's figurative language (1999: 461). However, when readers such as Barrell (or Levenson's "defensive theorists") adopt this practice, they reach a cul de sac. Byatt's figurative language resists a single interpretive key. It is dense with overt and over-determined symbols: the Alabaster children are described as "pale-gold and ivory creatures... with long pale silky lashes"; Byatt's novella shares a name with its female love

\footnotetext{
3 In addition to Byatt's neo-Victorian novels, John Glendening's Science and Religion in Neo-Victorian Novels examines the following examples: Penelope Lively's City of the Mind (1991), Graham Swift's Ever After (1992), Julie Diskie's Monkey's Uncle (1994), Liz Jensen's Ark Baby (1998), Andrea Barrett's The Voyage of the Narwhal (1998), Roger McDonald's Mr. Darwin's Shooter (1998), Mathew Kneale's English Passengers (2000), Tome Holland's The Bone Hunter (2001), among others.
} 
interest, Eugenia, who also shares her name with a rare and perfectly shaped butterfly, Morpho eugenia; after their marriage, William and Eugenia live at Bredely Hall (b-r-e-d-e), where Eugenia breeds (b-r-e-e-d) five children, including two sets of twins, in two years (Byatt 1992a: 4). Although figurative language is crucial to the composition and consumption of Byatt's fiction, the excess of referents in "Morpho Eugenia" challenges us to expand our reading practice beyond the search for stable metaphor to provide a hermeneutic model. Instead, we must imitate William's “analogical imagination [that] makes no attempt to stabilize the world" (Levenson 2001: 170). The instability of the realm of metaphor in "Morpho Eugenia" suggests that the reader's goal is to resist the desire for stability, to embrace the motion resulting from the trembling of these foundational beliefs (theology, Darwinism, the function of figurative language, reading for the Idea beneath the text), and to imitate that motion herself.

Even though "perpetual traveller" is a metaphor, because it suggests unending motion, it becomes a metaphor sui generis. By emphasizing the restless movement inherent to perpetual travel, this particular metaphor comfortably co-exists with the instability and variability of Byatt's figurative language. Using it enables us to recognize the centrality of metaphor in her work, but, then, to emphasize reading practice over searching for the Idea behind these novellas. However, in order to fully comprehend the active quality of Byatt's text and the reader's experience, we must examine the other element of Byatt's novella that equals metaphor's excessiveness and importance: intertextuality. While the plot of "Morpho Eugenia" does not stray from mid-Victorian England, the space of Byatt's text is flooded with manifold texts by other authors, both from the characters' (fictional) present and (our) historical past. These include excerpts from works by historical authors, such as John Milton, Ben Jonson, and Robert Browning. They include myths and fairy tales retold by the novella's characters, such as the nanny's rendition of Cupid and Psyche. They also include long passages from imaginary texts written by characterauthors, such as Sir Harald's treatise on natural theology and a fable by Matty Crompton (a single, semi-employed female relation of the Alabasters) entitled "Things Are Not What They Seem", which is included in its entirety, complete with illustrations. Shuttleworth claims that the textual density of Victorian natural history, which Byatt so successfully imitates, draws the reader "ever inward, so that [she] start[s] to inhabit that world of wonder and doubt, rather than standing outside of it" (2001: 154). This is one reason why Byatt's intertexts are so important - they counteract that inward pull and motivate the reader to continue moving, on and out of the space of the novel's frame.

Certainly, the term intertextuality can refer to a host of rhetorical devices including allusion, echo, parody, quotation, adaptation, pastiche, imitation, or 
hypertext. Kristeva's original definition of this term draws on Bakhtin's concept of dialogism and carnivalism and adds to it Barthes notion that all texts are intertextual, or, in her words, "any text is constructed as a mosaic of quotations; any text is the absorption and transformation of another" (Kristeva 1986: 37). Therefore, the term necessarily suggests interrelation not only among literary texts, but also among cultural idioms and social contexts. Kristeva does not limit the term to allusion, verbal echoes, or diachronic relationships with earlier work; she insists on a synchronic connection to "a contemporaneous field made up of literary and nonliterary texts" (Machecek 2007: 524). Most importantly, this extra-literary interrelation highlights the potentially subversive politics of intertextuality. By examining it, we illuminate what Mary Orr calls the "tacit critical agendas behind intertextuality" (2003: 7). Intertextuality can offer "a challenge to the cultural hegemony of originality or uniqueness over reproduction/copy" (Martin 2011: 149). This potential for resisting the hegemonic is essential to the connection this essay makes between intertextuality and reading practice. Understanding how Byatt deploys intertextuality will reveal the reading practice her novella recommends and how it empowers readers to resist a dominant narrative.

Like Byatt's excessive and unstable figurative language, the sheer number of intertexts can unsettle readers. According to Paul Dawson, there is a parallel to this discomfort in the response to a "perceived decline in the cultural authority of the novel over the last two decades" (2015: 5). In other words, many worry that, as the public sphere becomes more fragmented, the impact of the novel declines. Dawson believes that novelists have returned to the unfashionable and much-maligned omniscient narrator in order to combat this anxiety and to assist "information seeking citizens" as they navigate the "densely mediated landscape" of our digital culture (Birkets qtd. in Dawson 2015: 6; 2015: 7). He explicitly uses Byatt's omniscient narrator in Possession as an example of this practice. James Wood critiques this narrative mode, characterizing English novelists such as Eliot, Forster, Fielding, and Byatt as "remarkably intrusive, always breaking in to speak over their characters and tell us what to think" (2002: 18). However, it is difficult to find evidence of this habit in "Morpho Eugenia". Although the novella begins with an omniscient narrator in the Victorian realist tradition, perhaps to establish a foundational trust, this voice often disappears and, therefore, readers cannot rely on this device to guide them to the novella's Idea. Byatt provides more subtle cues to guide readers through her intertexts. For example, compared to the frame novel, the intertexts' font is slightly smaller and its indent slightly larger. As a result, the reader's eye moves in a different way than it would with a typical novel; it travels from one text to the other. However, beyond flagging its presence, Byatt does not offer explicit guidance for navigating this journey. She encourages 
a way of reading, not a particular meaning. Rather than the stabilizing force of the omniscient narrator, it is this reading practice that can help the "information seeking" citizen/reader to navigate the novella, and, if applied more broadly, to navigate the "densely mediated landscape" of contemporary society.

According to Alfer and Edwards de Campos, Byatt wants readers to experience a "dialogical engagement with the text, an open-minded curiosity about what the text is trying to say" (2010: 143). Her intertextuality invites such open-mindedness, curiosity, and responsiveness. By extending the novella's intertextuality beyond allusions to or citations of historical texts, by weaving texts penned by historical and imaginary authors into her novella without distinction, she assigns the same status to historical texts and imaginary texts written by character-authors. Instead of forming a hierarchy between the 'real' and 'imaginary' texts, she forms "a relation between equals" (Machacek 2007: 525). Her text becomes a textile woven with many different threads. Paradoxically, while the intertexts call attention to the frame novel's fictionality, they also make the fiction more real by aligning it with actual historical texts. ${ }^{4}$

While intertextuality is often linked with difficulty as a trademark of the postmodern novel, it serves a different purpose in Byatt's work. Instead of creating difficulty, instead of limiting the pleasure of reading to those who "get" the references, her fictional intertexts render the novella more democratic. While critics have noted the "Eliotic quantity of literary allusion and mythic parallels woven into her fiction", I would argue that they are not Eliotic in their effect - they do not seek to narrow the audience to the right kind of reader (Gitzen 1995: 94). In fact, Byatt often articulates her preference for the lay reader over the professional critic or academic and touts radio and television programs for "operating in the open world, not the university" (qtd. in Alfer and Edward de Campos 2010: 146). 5 The non-hierarchical nature and the increasing number of non-allusive intertexts render a search for an original source moot. Since there is no reference to "get", the intertexts can challenge the reader without quizzing her, activate her critical capacity and expand her enjoyment beyond a game of "catch the allusion".

This activation is key - as the reader's eye travels across the page, her mind engages with texts by various authors. The novella seeks to create movement, a journey beyond the plot. The focus on an active reader is central to many

\footnotetext{
${ }^{4}$ For more on this type of paradoxical outcome see Linda Hutcheon's chapter "Historicizing the Postmodern: The Problematizing of History" in A Poetics of Postmodernism: History, Theory, Fiction. Frederick Holmes and Mariadele Boccardi both discuss Hutcheon's theory in relation to Possession.

5 In the introduction to her collection of essays On Histories and Stories, Byatt celebrates that "readers at large, who are spending more and more time discussing books - all sorts of books - in the vulgar tongues and frank language of every day, in book clubs." (6)
} 
theories of readership over the past half century, and a number of theorists use a metaphor that suggests movement. Wolfgang Iser describes the reader as "wandering" through a text, "travel[ing]" between "textual segments" (2010: 1528). Roland Barthes's essay "From Work to Text" ("De l'oeuvre au text") outlines seven characteristics of Text (texte) versus Work (oeuvre). These characteristics succinctly capture the components of Byatt's intertextuality that lead to the perpetual-traveller reading practice. In his discussion of texte's inherent plurality, playing on the etymological connection between texte and textile, Barthes begins by comparing "the reader of the Text" to "someone at a loose end" (Barthes 2010: 1328). The texte/textile is not complete - some threads hangs loose, waiting for the reader to take them up. Then he shifts to the metaphor "strolling" to describe the reader's actions:

This [reader] strolls - it is what happened to the author of these lines, then it was that he had a vivid idea of the Text - on the side of a valley, a oued flowing down below (oued is there to bear witness to a certain feeling of unfamiliarity); what he perceives is multiple, irreducible, coming from a disconnected, heterogeneous variety of substances and perspectives...All these incidents are half-identifiable: they come from codes which are known but their combination is unique, founds the stroll [promenade] in a difference repeatable only as difference. (Barthes 2010: 1328-29)

In this striking passage, the reader/author strolls along a valley in a strange and unfamiliar place. Oued is the Wadi word for a streambed or valley. By using this foreign term for something that does not exist in the author's country of origin, Barthes characterizes the reader's experience with the text as an encounter with otherness, as adventurous, even dangerous. In the French, the word translated "feeling of unfamiliarity" is dépaysement - the reader is literally un-country-ed in this encounter and left to wander alone without guidance (Barthes 1971: 73). Oued also suggests the transformative nature of this encounter. The oued is dry all year, except for the rainy season - then it is flooded with water and transformed into an entirely different landscape. Byatt's intertextuality is akin to the Barthian texte - not singular, but plural; not an object, but a process. Byatt weaves her intertexts into the frame story and the reader reenacts that weaving motion. If we imagine her intertexts as a "disconnected, heterogeneous variety of substances and perspectives", then we can trace how she encourages the reader to stroll through these intertextual passages and create her own unique combination.

The final characteristic of texte in Barthes's essay, and, of course, one to which he would return, is pleasure. Whether or not readers enjoy reading is a theme within Byatt criticism, too, although scholars typically turn to Possession to support their claims. Ann Marie Adams argues that Possession does create a 
particular reading practice, but not a particularly enjoyable one. She contends that the combination of its romance plot, its intrusive narrator, and Byatt's subtextual insistence that critics impair readers' access to the Author's message force the reader to accept a singular reading practice and thereby undermine her pleasure. According to Adams, rather than liberated, "enchanted readers", Byatt' readers are "constructed and constrained" (2003: 108). On the other hand, Mark Hennelly posits a dual pleasure of the text in Possession, for Byatt's readers and for the novel's character-readers, two academics for whom reading is both work and pleasure. He examines "the motif of 'repeating patterns" to establish the "greedy reading" practice that Possession recommends and the "cognitive and visceral" pleasures it affords (2003: 445). His version, which combines work and pleasure, activity and enjoyment, more closely aligns with my interpretation of the effect of intertextuality in "Morpho Eugenia".

In order to demonstrate precisely how intertextuality in "Morpho Eugenia" creates the perpetual-traveller reading practice, I will examine two intertexts in particular: William's personal journal and his book of natural history, The Swarming City. While other critics have focused on the novella's allusions to historical texts (e.g. Judith Fletcher's "The Odyssey Rewoven") or the complete fictional intertext, Matty Compton's "Things Are Not What They Seem", (e.g. Michael Lackey's "Prolegomena to Any Future Theory"), this essay will focus on two imaginary works that bookend the novella's plot. These two texts coincide with William's travels - his arrival and departure from Bredely Hall respectively. Furthermore, they track William's search for his vocation, a career that requires work yet affords pleasure, activity that will help him balance his public and private life. His search for a vocation parallels our search for a reading practice and by tracing William's search through the (inter)texts that foster his transformation, we will discover the reading practice that has the potential to transform readers as well as reading.

William's journal jumpstarts his journey toward a vocation. The narrator tells us that, as a young man, son of a Yorkshire butcher, William began keeping a journal in order to create "an accurate record, of the development of the mind and character of William, who still meant to be a great man" (Byatt 1992a: 11). The description of his developing mind and character moves in tandem with his burgeoning authorship. After he began collecting scientific specimens, "His journal was for the first time alive with a purposeful happiness" (Byatt 1992a: 11). Once he discovers social insects, "His journal became the journal of an ant-watcher" (Byatt 1992a: 12). His journal transforms yet again once he plans to travel to the

\footnotetext{
6 Hennely uses Byatt's term from the introduction to Passions of the Mind: "Greedy reading made me want to write, as if this were the only adequate response to the pleasure and power of books" (xiii).
} 
Amazon. In this stage of metamorphosis, his writing becomes more complex: "The journal[s] began to intermingle a rapt, visionary note with detailed practical sums for outfitting, for specimen boxes, with names of ships, with useful addresses" (Byatt 1992a: 12). The different registers of his internal and external life combine in this text and create a textual vision of his impending future and vocation.

Once his travels commence, William begins corresponding with Harald Alabaster and a vision of his vocation emerges: "William wrote [...] the letters of a great naturalist from an untrodden wilderness, spiced with an attractive self-deprecating humour" (Byatt 1992a: 13). Now the "ant-watcher" has graduated to "great naturalist". His writing both produces and reflects this new identity, not only in terms of content, but also in terms of style. An "ant-watcher" might record the movements of insects; a "great naturalist" describes his observations with drama and humor. These aesthetic changes represent William's transformation, at least in his self-perception, from amateur to expert.

The journal transforms along with William physically as well as textually. The narrator describes his "tropical journal" as "much stained - by the paraffin in which their box had once been doused to prevent their being eaten by ants and termites, by traces of mud and crushed leaves from canoe accidents, by salt water like floods of tears" (Byatt 1992a: 13). The journal gained tactile qualities during William's travels - his experiences in the Amazon bestowed it with new physical characteristics in addition to the professional and personal experiences recorded within its pages. With the journal, textual comingling becomes materially instantiated. ${ }^{7}$

William's personal and professional discoveries are inextricably linked with their inscription, with this comingled text. Despite the dangers, disasters, and privations, his Amazonian life and the process of writing about it undeniably exhilarate him:

He had peered into these pages [of his journal] by the light of burning turtle oil, and had recorded his solitude, his smallness in the face of the river and the forest, his determination to survive, whilst comparing himself to a dancing midge in a collecting bottle. He had come to be addicted to the written form of his own language, which he hardly spoke at all. (Byatt 1992a: 13-14)

He becomes even more obsessed with written language as his spoken language disappears. Some critics focus on the ontologizing power of the spoken word in this novella, in particular, the act of naming. Lackey, in his analysis of Matty's

\footnotetext{
Elizabeth Hicks thoughtfully examines the connection between material objects and the identity of individuals who make and/or collect them in Byatt's work. See "Public and Private Collections in A.S. Byatt's The Children's Book".
} 
intertextual fable, observes that the character Mistress Pan Demos "has the power and authority to control her world through language ('you must do as I say'), which means that [anyone], while in her world, cannot use language to define themselves or to control their own subjectivity" (Byatt 1992a: 136; original emphasis). Note that her powerful language is spoken - you must do as I say. The power of naming is undeniably a motif within the novella, and other Victorian and neoVictorian fiction, connected to the era's extensive discoveries of new species. The naming method was generated by a combination of England's imperial project and the new Darwinian philosophy of interconnectivity. According to Michelle Weinroth, the process of naming "affords the individual both godly power and joy to organize, colonize, and ascribe meaning to unnamed things" but it is "also an incarcerating force", the latter demonstrating what she calls the novella's "postcolonial critique" of "Victorian Englishness" (Byatt 1992a: 187). For William in the Amazon though, the written word takes precedence. Indeed, this practice is framed as addiction. He needs the written record of his travels as much as the travels themselves. Both are essential to the discovery of his vocation.

His addiction persists from his past travels to the novella's present. His journal, the "accurate record" of the development of his "mind and character" led him to other texts, which he likewise incorporates into his journal (Byatt 1992a: 11). The narrator explains: "Writing gave him a taste for poetry. He read and reread Paradise Lost and Paradise Regained [...] and an anthology of Choice Beauties of our Elder Poets. It was to this he turned now" (Byatt 1992a: 14). Up to this point, the reader has merely encountered the narrator's descriptions of William's journal. Now that mediating voice ceases. "[N]ow," William copies out lines from a Ben Jonson poem into his journal, which Byatt includes as a block quote in her text. William uses this passage to work out his feelings for Eugenia and to relish the painful pleasure of falling in love. The reader has work to do too. Encountering Jonson, dropped into the novella, pushes the interpretive onus onto the reader. She must figure out how to navigate a text that is simultaneously Jonson's, William's, and Byatt's.

This first intertext, Jonson's poem, is soon followed by another. The narrator's voice returns, briefly, to tell us that William remembered a line from a fairy story he heard as a child, "I shall die if I cannot have her"' (Byatt 1992a: 15). This intertextual passage is both familiar and strange. Byatt uses double quotation marks, suggesting that William is copying it out verbatim. However, although it recalls countless stories, it does not have a precise referent. In this way, Byatt offers her reader a middle ground between Jonson's (historical) and William's (imaginary) text. It belongs to everyone and no one, part of the cultural discourse of fairy tales, quotable, available, yet unattributable. This exemplifies how Byatt's 
intertextuality denies the search for an origin that would provide a direct path to interpretation. Instead, she encourages readers to embrace the "feeling of unfamiliarity" they experience as they encounter journal entries, poems, and fairy stories in rapid succession (Barthes 2010: 1328).

The parallel between William's journal, embedded in Byatt's novella, and Jonson's poem, embedded in William's journal, is undeniable. The doubleness of Byatt's page, with two sets of fonts and indentations, parallels the doubleness of William's journal, practical and visionary, physical and textual. Furthermore, as one of the only items that survived shipwreck, the journal brings his travels back to England literally and metaphorically. It provides a record of his life as a great naturalist and keeps images of his Amazonian travels alive in his mind's eye. The duality of these texts introduces a pervasive doubling throughout Byatt's novella.

As Alfer and Edwards de Campos point out, the phenomenon of doubling 8 is, "of course, one that readers of Byatt's [...] fiction are already familiar with" (2010: 152). Doubleness is explicitly invoked by the narrator and the trope accumulates symbolic force as the novella continues. Upon returning to England, the narrator tells us that William experiences "double vision" (Byatt 1992a: 7). He simultaneously sees moments from his travels alongside events in the present; a figurative version of what Byatt's reader sees on the pages of the novella. "Morpho Eugenia" opens with a ball and, goaded by Lady Alabaster to rectify the perennial lack of gentleman partners, William finds himself spinning round the dance floor with the youngest Miss Alabaster. The narrator tells us that the waltz reminds him of other waltzes danced in Pará and Manáos "with olive-skinned and velvet-brown ladies of doubtful virtue and no virtue" (Byatt 1992a: 5). The parallel moment in the present distresses him: "There was something alarming in the soft, white creature in his arms, at once so milky-wholesome and so airily untouchable" (Byatt 1992a: 5). The paradoxical doubleness of the present, his perception of the Alabaster dance partner once he has recalled a comparable experience in the Amazon, alarms him.

The sense of alarm increases when he partners with Eugenia. Voicing William's thoughts, the narrator describes her as "both proudly naked and wholly untouchable" and at this thought William experiences "to his shame and amazement, unmistakable stirrings and quickenings of bodily excitement in himself" (Byatt 1992a: 7). This sensation recalls a very different kind of dance, when he was: "grabbed and nuzzled and rubbed and cuddled with great vigour by women with brown breasts glistening with sweat and oil, and shameless fingers. Nothing he did now seemed to happen without this double vision, of things seen

8 They use the term "double effect". 
and done otherwise, in another world" (Byatt 1992a: 7, my emphasis). Everything he does "now" happens alongside "things seen and done otherwise"; this alabaster lady has a "velvet-brown" Other. Ultimately, the problem with this double vision is its intensely personal (sexual) manifestation. William was invited to Bredely Hall because his letters to Harald Alabaster established him as a "great naturalist". Once he enters Bredely Hall, however, his path shifts. Instead of a scientist-explorer conquering the Amazonian jungle, he becomes a character in a marriage plot. When dancing with love interest Eugenia, he does not recall professional activities from his travel; he recalls distinctly more personal ones.

While sitting in church with the Alabasters, William experiences a recurrence of this double vision. During Harald's Anglican sermon, he remembers an altogether different spiritual practice, an all-male Amazonian ceremony:

He remembered the fleeing women, faces covered, sitting amongst the decorous English family, men on one side, women on another, watching Eugenia's pink tongue moisten her soft lips. He felt he was doomed to a kind of double consciousness. Everything he experienced brought up its contrary image from out there, which had the effect of making not only the Amazon ceremonies but the English sermon seem strange, unreal, of an uncertain nature. (Byatt 1992a: 27-8; original emphasis)

Imagining the Amazonian women in this chapel alongside a vision of Eugenia's pink, soft, and moist tongue and lips transforms the troubling double vision he had at the dance to an even more troubling state: double consciousness. ${ }^{9}$ Now that he lives with the Alabasters at Bredely Hall, he must grapple with the unsettling coincidence of his current life and his other life, his mind must continually confront "out there" and in here. Indeed, the missing subject in Byatt's syntax does not clearly indicate who is doing the "sitting" - William or the "fleeing women" - suggesting the perilous state of William's subjectivity. Doubleness has advanced from vision to consciousness - it moves further inward and threatens not only William's vocation but also his idea of self. Like Barthes's encounter with the oued, William's double-vision of foreign faces juxtaposed with decorous English ones evokes a feeling of radical unfamiliarity. William, however, seems unable to take these threads and weave them together. His mind seems to flee from the images, not stroll among them. Bredely Hall does not allow the freedom of movement to wander in search of his vocation.

The most troubling part of the ballroom and church scenes seems to be William's inability to sort, distinguish, or impose order on these unruly thoughts.

\footnotetext{
9 It is impossible to use this phrase without invoking W.E.B. Dubois and the concept of a racialized Other. Although this is not the primary focus of my argument, the invocation underscores the racial component of William's double vision.
} 
This discomfort parallels some readers' discomfort with the inability to sort, distinguish, or impose order on Byatt's unruly text. William is afflicted by the same unruliness in his work for Harald, seemingly without any pleasure. Facing the mountain of specimens that Harald purchased "with no clear priority of interest", William feels unequal to the task of systematically sorting these "higgledypiggledy" treasures (Byatt 1992a: 28). ${ }^{10}$ The narrator states: "He could not devise an organising principle" to impose upon the "plethora of beetles or [...] sudden plague of frogs" (Byatt 1992a: 29). The word "plague" here recalls the "plague[s] of biting flies" he described in the jungle. These are the only two times Byatt uses the word "plague" to describe an overwhelming number of troubling objects. Its repetition here transfers the subtext of fear and danger written in the journal from living specimens to dead ones, from his work in the past to his present occupation. Furthermore, since this passage immediately follows the scene in the church, the reader is encouraged to connect the two scenes of discomfort, alike in their lack of organization, and in William's inability to place things where they belong (memories or specimens), or even to know where that place is ("out there" or in here). He wants to devise an organizing principle for his career, his life, his (literal and metaphorical) place in the world. William is doing a kind of scientific work, but, like readers searching for an "organising principle" to unlock the Idea behind the novella, it is the wrong kind of work. By misplacing his goal, he puts the search for a true vocation in peril.

Searching for an organizing principle to sort Harald's higgledy-piggledy collection is not the work that William wants to be doing, nor is this the model for reading that Byatt recommends. He wants to return to the Amazon to research an unstudied ant species called Eciton burchelli. In his description of this ant, he introduces our metaphor for reading practice: William suspects these ants are "perpetual travellers who form only temporary encampments... they must be perpetually on the move in order to survive" (Byatt 1992a: 18-19; original emphasis). Although his wealthy host promises to fund an expedition in the future, he persuades William to extend his visit at Bredely Hall in the meantime. Delaying this venture stalls his search for a vocation, a life in which work and pleasure comfortably co-habitate.

William's journal introduces the novella's intertextuality and establishes the doubleness of William's text and his experience of life in England. However, after the reader's first direct glimpse of the journal's pages, they disappear entirely from

\footnotetext{
${ }^{10}$ Byatt takes this unusual descriptor from one of Darwin's letters written shortly after the publication of Origin of the Species in 1859: "I have heard by round about channel that Herschel says my Book 'is the law of higgledy-pigglety.' What this exactly means I do not know, but it is evidently very contemptuous. - If true this is great blow \& discouragement" (Darwin 1859: np).
} 
the novella. After he marries Eugenia and the desire he recorded in his journal is fulfilled ("I shall die if I cannot have her"), after the Amazonian travels that inscribed life and texture into their pages end, the text seems to have outlived its utility. Upon the birth of his fifth child, William contemplates his life: "For he was not happy. He had perhaps never been exactly happy, though he had had what he desired, what he had written in his journal he had desired. [Note the verb tense here - had desired.] He was unhappy for many reasons. Most of all, and every day, he worried that he had lost his sense of purpose, even vocation" (Byatt 1992a: 84). Originally, his journal led him toward his vocation, but his desire for Eugenia derailed his career and trapped him in the domestic space of Bredely Hall. Here, a balance of personal and professional desire could not be sustained, and the former swallowed up the latter. Now he needs a new kind of writing to find and fulfill a different desire, a text to take the journal's place, one that can once again help him find his vocation and render his life "alive with a purposeful happiness", as the journal once did (Byatt 1992a: 11).

Matty Crompton leads him to just such a text. When she suggests that they observe the local species of social insects and record their findings, William feels that, by "put[ting] him in the way of purposeful activity again" she had "transfigured [his] prospects" (Byatt 1992a: 88, 109). It is key, though, that this transfiguration hinges on authorship. This time, he writes a naturalist work of nonfiction entitled The Swarming City: A Natural History of a Woodland Society, its polity, its economy, its arms and defences, its origin, expansion and decline, about twelve pages of which are embedded within Byatt's novella. His journal chronicled a personal journey that led to a professional, public persona. Now this public, professional text will lead him to personal happiness. It enables him to escape the stagnant domestic space of Bredely Hall and shift his romantic interest from Eugenia, a creature of that space, to Matty, someone eager to travel, a suitable partner for his personal and professional life.

More than a uni-dimensional, professional text, The Swarming City's generic complexity endows it with transformative potential for author and reader. Initially, William resists Matty's suggestion to write a book, claiming that he does not have time to write a "major scientific study" (Byatt 1992a: 108). She counters by suggesting that he write a "natural history", a term that accounts for the multifaceted text that she envisions. She imagines this book as: "something very interesting to a general public, and yet of scientific value"; "useful - and dare I say it - profitable"; William could share his "very great knowledge" but with the requisite "drama [...] to appeal to the general public"; the book will be "delightful as well as profound and truthful" (Byatt 1992a: 108-109, 120; original emphasis). Unlike William and his journal, in conceiving of this text Matty focuses on the 
reader as much as the writer. She wants to find an appropriate venue for William's talents, but also to shape his text to appeal to a real audience and market. Matty's book concept is more democratic. It has the potential to provide pleasure and edification; scholarship and financial gain. Like Byatt, Matty envisions a reader's dialogical, open-minded, and curious engagement with the text.

Writing The Swarming City as Matty recommends leads William to his vocation. William was the author and sole reader of his previous text, his journal, and the genre's inherent insularity limited its effectiveness. It may sound counterintuitive to claim that a journal, which undoubtedly encourages and records self-reflection, could, by its very nature, hinder personal development. It may sound equally strange to suggest that the journal that begat the "ant-watcher" and "great naturalist" could not precipitate William's professional development. But if it had begun to do either, William himself confirms that this progression ceased at Bredely Hall. Personally, he became a somewhat estranged husband and professionally, he was demoted to an assistant for Harald and a governess during the children's science lessons.

No resident of Bredely Hall maintains a proper balance of public and private, personal and professional, and no member of the Alabaster family finds happiness or success in either realm. Insular to the extreme, this domestic space engenders terrible, taboo behaviors, even an incestuous relationship between Eugenia and her brother Edgar. In this sense, Bredely Hall can be read as an anti-Darwinian space that rejects the essential precursor to progress, genetic diversification. Certainly such a place would be toxic to the continued development of a "great naturalist". The lovely, lily white Eugenia's relationship with Edgar leads to the death of her fiancé, the failure of her marriage to William, and the propagation of several sibling-children. Likewise, while Edgar appears to represent the ideal Victorian male, his personality is dangerously unbalanced. Byatt describes his ideal qualities: "a big, muscular man, his blond hair crimping in windswept, regular waves over his long head"; the eldest son and heir of "an ancient and noble family, who had always been very pure-blooded"; equally comfortable waltzing ("his large feet moved quickly and intricately, tracing elegant skipping patterns") and riding horses (Byatt 1992a: 5, 25, 5). However, William observes that Edgar's body displays a stifled, "pent-in force" that foreshadows the ugly private behaviors that Edgar conceals, his hidden "centaur or satyr" (Byatt 1992a: 123, 29). In addition to being his sister's longtime lover, Edgar is also an unabashed rapist. When William encounters Edgar in the scullery raping a young female servant, Amy, who William had noted earlier was "no more than a child", Edgar shows no embarrassment or remorse (Byatt 1992a: 86-7). Rather, he attacks William for interrupting them and demands that William apologize and leave. Neither Eugenia nor Edgar travel from 
Bredely Hall, neither has a profession to balance his or her personal life, and neither seeks nor discovers a vocation such as William pursues. As Shuttleworth points out, "William chooses 'dusky'-skinned Matty, member of hardier stock than those effete, interbred specimens produced by the leisured aristocratic life at Bredely Hall" (2001: 158). William could never enjoy a happy marriage in the Alabaster home but The Swarming City will enable a happy marriage of desire and vocation for William and Matty.

Writing The Swarming City enables the appropriate balance of public and private in William's re-emerging vocation and reverses the valence of the disorienting double vision that he experienced earlier in the novella. The book's multiplicity, as Matty envisions it, appeals to publishers and therefore provides him with the financial resources to leave Bredely Hall and its immoderate privacy. With his book advance, he and Matty purchase two berths on Captain Papagay's ship and journey to the Amazon together. Instead of halting his forward trajectory as the journal and Eugenia did, postponing his travels and rooting him at Bredely Hall, this text renders him a traveller once again. Ultimately, The Swarming City leads him back to the Amazon, back to his career, accompanied by a partner in work and romance.

I suggest that we can reimagine the experience of Byatt's readers when they encounter embedded texts as a kind of travel too. It's not just what they see, but the places they go as they read further and further into another story. It's the way their eyes move over the page on a self-guided journey as they navigate from texts by one author to another, and back again. The multiplicity of intertexts in "Morpho Eugenia" undermines a hierarchical approach to reading. It rejects an organizing principle that would privilege one text in order to suppress another. Instead of the strict hierarchy of, for example, a manor house or a family tree, the novella's intertextuality is better represented by the continual movement of a perpetual traveller. William and Byatt encourage their readers to compare ants with humans, to see what the ants can show us about ourselves, but then to look beyond such a figure because "Analogy is a slippery tool" (Byatt 1992a: 116). The metaphor of perpetual traveller reveals William's compulsion to keep moving within and beyond the novella, a compulsion shared by readers. Both The Swarming City and "Morpho Eugenia" render William a perpetual traveller. While Captain Papagay does return to his wife in England in the next novella, "The Conjugial Angel", William and Matty do not reappear. William un-countrys himself, becomes a perpetual traveller, and thereby achieves happiness and satisfaction. For Byatt's reader, his journey never ends.

If Byatt's readers embrace the reading practice "Morpho Eugenia" recommends, their journeys will never end either. Some critics have disparaged neo-Victorian 
novels such as Angels and Insects for presenting thinly veiled nostalgia for Britain's colonial past, for resisting the globalizing trend in new British fiction by reenacting outdated frameworks of perception. I would argue that the perpetualtraveller reading practice challenges that perception by resisting a hegemonic narrative, by rejecting the idea of origin or destination. Like William, if the reader un-countrys herself when confronted with otherness, if she engages with and embraces the unfamiliar, she will embark on an endless global journey. Rather than colonial nostalgia, Byatt's work transforms the desire to return to a Victorian past into a desire never to return to anywhere, or to acknowledge that such an origin exists. This produces a distinctly, even radically global model of readership. Byatt's intertextuality creates a kind of Barthian texte without beginning or end. Like William, Byatt's reader becomes a perpetual traveller, compelled to roam from text to intertext, and thoroughly enjoys the journey.

\section{REFERENCES}

Adams, Ann Marie. 2003. "Dead Authors, Born Readers, and Defunct Critics: Investigating Ambiguous Critical Identities in A.S. Byatt's Possession". The Journal of the Midwest Modern Language Association 36 (1): 107-124.

Alfer, Alexa and Amy J. Edwards de Campos. 2010. A.S. Byatt: Critical Storytelling. Manchester: Manchester UP.

Barrell, John. 1992. "When will he suspect?" London Review of Books, 19 Nov. 1992, 18-19.

Barthes, Roland. 1971. Le Bruissement de la Langue. Paris: Éditions du Seuil.

Barthes, Roland. 2010. "From Work to Text". The Norton Antbology of Theory and Criticism. Ed. Vincent B. Leitch. New York: W.W. Norton. 1326-1331. Trans. Stephen Heath.

Boccardi, Mariadele. 2009. The Contemporary British Historical Novel: Representation, Nation, Empire. New York: Palgrave Macmillan.

Byatt, A. S. 1992. Angels and Insects. New York: Vintage Books.

Byatt, A. S. 1992. Passions of the Mind: Selected Writings. New York: Turtle Bay Books. Byatt, A. S. 2000. On Histories and Stories: Selected Essays. Cambridge: Harvard UP. Darwin, Charles. "To Charles Lyell [10 December 1859]". Darwin Correspondence Project, <https://www.darwinproject.ac.uk/letter/?docId=letters/DCP-LETT-2575. $\mathrm{xml}$;query=higgledy-pigglety; brand=default $>$. (Accessed 25 Feb. 2016)

Dawson, Paul. 2015. The Return of the Omniscient Narrator: Authorship and Authority in Twenty-First Century Fiction. Columbus: Ohio State U. 
Martin, Elaine. 2011. "Intertextuality: An Introduction". The Comparatist, 35 (May), 148-151.

Fletcher, Judith. 1999. "The Odyssey Rewoven: A. S. Byatt's Angels and Insects". Classical and Modern Literature: A Quarterly 19 (3): 217-231.

Gitzen, Julian. 1995. “A. S. Byatt's Self-Mirroring Art”. Critique 36 (2): 83-95.

Glendening, John. 2013. Science and Religion in Neo-Victorian Novels: Eye of the Ichthyosaur. New York: Routledge.

Hansson, Heidi. 1999. "The Double Voice of Metaphor: A. S. Byatt's 'Morpho Eugenia”. Twentieth Century Literature 45 (4): 452-466.

Hennelly, Mark M., Jr. 2003. “'Repeating Patterns' and Textual Pleasures: Reading (in) A.S. Byatt's Possession: A Romance". Contemporary Literature 44 (3): 442-471.

Hicks, Elizabeth. 2011. "Public and Private Collections in A.S. Byatt's The Children's Book". Mosaic 44 (2): 171-185.

Holmes, Frederick M. 1997. The Historical Imagination: Postmodernism and the Treatment of the Past in Contemporary British Fiction. Victoria: English Literary Studies.

Hutcheon, Linda. 1988. A Poetics of Postmodernism: History, Theory, Fiction. New York: Routledge.

Iser, Wolfgang. 2010. "Interaction between Text and Reader". The Norton Anthology of Theory and Criticism. Edited by Vincent B. Leitch. New York: W.W. Norton. 1524-1532.

Jameson, Fredric. 1991. Postmodernism Or, The Cultural Logic of Late Capitalism. Durham: Duke UP.

Keen, Suzanne. 2006. "The Historical Turn in British Fiction". A Concise Companion to Contemporary British Fiction. Ed. James F. English. Malden: Blackwell. 167-187.

Kristeva, Julia. 1986. "Word, Dialogue and Novel". The Kristeva Reader. Ed. Toris Moi. Oxford: Blackwell. 34-61. Trans. Seán Hand.

Lackey, Michael. 2008. “A.S. Byatt's 'Morpho Eugenia': Prolegomena to Any Future Theory". College Literature 35 (1): 128-147.

Levenson, Michael. 2001. "Angels and Insects: Theory, Analogy, Metamorphosis". Essays on the Fiction of A.S. Byatt: Imagining the Real. Eds. Alexa Alfer and Michael J. Noble. Westport: Greenwood Press. 161-174.

Machacek, Greg. 2007. "Allusion”. PMLA. 122 (2): 522-536.

Orr, Mary. 2003. Intertextuality: Debates and Contexts. Cambridge: Polity Press. 
Poznar, Susan. 2004. "Tradition and 'Experiment' in Byatt's 'The Conjugial Angel'”. Critique 45 (2): 173-189.

Shuttleworth, Sally. 2001. "Writing Natural History: 'Morpho Eugenia”. Essays on the Fiction of A.S. Byatt: Imagining the Real. Eds. Alexa Alfer and Michael J. Noble. Westport: Greenwood Press. 147-160.

Thorne, Matt and Nicolas Blincoe, eds. 2001. All Hail the New Puritans. London: Fourth Estate, 2001.

Weinroth, Michelle. 2005. "Morpho Eugenia' and the Fictions of Victorian Englishness: A.S. Byatt's Postcolonial Critique”. English Studies in Canada 31 (2-3): 187-222.

Wood, James. 2002. "V.S. Pritchett and English Comedy". On Modern British Fiction. Ed. Zachary Leader, Oxford: Oxford UP. 6-17. 